\title{
Giordano Bruno and Bonaventura Cavalieri's theories of indivisibles: a case of shared knowledge
}

\section{Paolo Rossini}

To cite this article: Paolo Rossini (2018) Giordano Bruno and Bonaventura Cavalieri's theories of indivisibles: a case of shared knowledge, Intellectual History Review, 28:4, 461-476

To link to this article: https://doi.org/10.1080/17496977.2018.1502979

曲 Published online: 23 Oct 2018.

Submit your article to this journal ๔

View Crossmark data $\nearrow$ 


\title{
Giordano Bruno and Bonaventura Cavalieri's theories of indivisibles: a case of shared knowledge
}

\author{
Paolo Rossini \\ Institute of Humanities and Social Sciences, Scuola Normale Superiore, Pisa, Italy
}

\begin{abstract}
At the turn of the seventeenth century, Bruno and Cavalieri independently developed two theories, central to which was the concept of the geometrical indivisible. The introduction of indivisibles had significant implications for geometry - especially in the case of Cavalieri, for whom indivisibles provided a forerunner of the calculus. But how did this event occur? What can we learn from the fact that two theories of indivisibles arose at about the same time? These are the questions addressed in this paper. Relying on the methodology of "historical epistemology", this paper asserts that the similarities and differences between the theories of Bruno and Cavalieri can be explained in terms of "shared knowledge". The paper shows that the idea - on which both Bruno and Cavalieri build - that geometrical objects are generated by motion was part of the mathematical culture of the time. Tracing this idea back to its Pythagorean origins thus sheds light on the relationship between motion and continuum in mathematics.
\end{abstract}

\section{KEYWORDS}

Giordano Bruno; Bonaventura Cavalieri; Pythagoreanism; history of mathematics; historical epistemology; shared knowledge

As is well known, the first to problematize the composition of the continuum was Aristotle who, reacting to Democritus's atomism, denied that indivisibles can be part of a continuum. ${ }^{1}$ Since then, the problem of the continuum has continued to be discussed by philosophers, theologians and mathematicians. It soon became one of those topics on which the discussions between Aristotelians and anti-Aristotelians were more vivid. ${ }^{2}$ The term "labyrinth of the continuum", made famous by Leibniz who borrowed it from Libertus Fromondus, gives us a sense of how the problem of the continuum was perceived as a tremendous challenge by early modern scholars. ${ }^{3}$

As to mathematics, classical Euclidean geometry endorsed an Aristotelian anti-atomistic view of the continuum by allowing indivisibles only as extremities and not as parts of the geometrical continuum. This explains why when in the seventeenth century Bonaventura Cavalieri (1598-1647) introduced a method of indivisibles his enterprise was met with skepticism by his fellow mathematicians, and Cavalieri was called to defend his method from the charge of atomism. Cavalieri's method, however, is now regarded as a pivotal moment in the history of modern mathematics, for it opened the doors of geometry to infinitely small quantities, and from there to the development of the calculus. 
As a matter of fact, discussions about the composition of the geometrical continuum were going on even before Cavalieri elaborated his method. Objections to an Aristotelian understanding of the geometrical continuum had already been raised by Giordano Bruno (1548-1600) who, like Cavalieri, attempted to establish a geometry of indivisibles. More precisely, Bruno's geometry was built on the concept of the minimum, by which he meant the smallest indivisible part which all geometrical objects are composed of. Therefore, the concept of the geometrical indivisible which features in Cavalieri's method seems to find an earlier conceptualization in Bruno's theory of minima. In spite of this, Bruno is considered an anti-mathematician or a poor mathematician even by Bruno scholars, and $a$ fortiori is neglected in the traditional accounts of modern mathematics.

This being the case, a comparison between Bruno and Cavalieri as proposed in this paper may help to form new insights into Bruno's mathematical activities, and thus lead to a reassessment of Bruno's overall attitude toward mathematics. However, for this comparison to be properly understood and to avoid making unwarranted claims, it is necessary to point out the grounds on which such a comparison is made. In other words, we need to answer the question of what Bruno and Cavalieri have in common besides the intuition of geometrical indivisibles. Could this intuition, which each author characterizes in his own way, have stemmed from shared ground or as a response to a common problem?

To be clear, I rule out the possibility that Cavalieri might have been a reader of Bruno, and that therefore Bruno might have influenced Cavalieri in the making of his method of indivisibles. In fact, no direct connection is likely to be found between Bruno and Cavalieri, and it is more advisable to consider Bruno and Cavalieri independently from each other - at least in this respect. Yet this does not preclude that a connection may be offered by a third party - that perhaps Bruno and Cavalieri relied on a body of shared knowledge that could account for the similarities between their two theories.

The existence of a shared knowledge, conceived as an important factor in the development of science, is a defining characteristic of what has been called "historical epistemology". In this view, special emphasis is placed on those collective factors (shared knowledge, shared problems, mental models) whose importance is usually overshadowed in the more widespread narrative, wherein science is merely the result of individual discoveries. On accepting historical epistemology, science can no longer be seen as the enterprise of a few isolated heroes; rather, attention must also be paid to the so-called minor characters. For instance, alongside Galileo we need to consider his less famous contemporary Thomas Harriot who, as shown by Matthias Schemmel, was engaged in solving problems similar to those focused on by Galileo. By studying Harriot, Schemmel suggests, we not only gain a better understanding of Harriot's own work but also a more complete picture of how modern science emerged. For without a comparison of Galileo and Harriot "our understanding of the shared knowledge of early modern thinking [...] will remain incomplete and biased". 5

Mutatis mutandis, we can apply what Schemmel says about Galileo and Harriot to the case of Bruno and Cavalieri. A comparison between these two authors, besides enriching the image we have of Bruno as a mathematician, might also clarify the historical conditions under which the rise of geometrical indivisibles occurred. In my view, it can help to identify an important component of early modern mathematical culture - that 
is, the Pythagorean tradition from which both Bruno and Cavalieri gained the insight that geometrical objects are generated by motion.

A possible methodological objection to this claim might concern the place occupied by Bruno in the proposed comparison. Why should a comparison between Bruno and Cavalieri be revealing of shared knowledge? Why could the same information not be obtained by a comparison between Cavalieri and one of the many seventeenth-century mathematicians who made an effort to improve the concept of the geometrical indivisible (e.g. Barrow, Torricelli, Pascal)? After all, as underlined by Vincent Jullien, the development of the method of indivisibles certainly started with Cavalieri, but was carried out by means of a "collaborative endeavor". 6

My answer to this objection appeals to the above-mentioned independence of Cavalieri from Bruno. Had Cavalieri been familiar with Bruno's works, he could easily have borrowed the idea that geometrical objects are generated by motion from Bruno himself. In that case, we would not be able to speak of shared knowledge. As noted by Schemmel, independence is a key factor for historical epistemology to be effective, otherwise the search for shared knowledge boils down to a "trivial matter". 7 Such an independence in not guaranteed in the case of seventeenth-century "indivisibilists" who explicitly refer to Cavalieri as the father of their methods.

But shared knowledge is not only a viable option to account for the similarities between Bruno's and Cavalieri's theories - it may also explain why they differ on several points, such as the composition of the geometrical continuum and the number of indivisibles which constitute each geometrical object. In fact, one may argue that the theories of Bruno and Cavalieri appear to have more differences than similarities, not to mention that they are not comparable in terms of effectiveness. Bruno's theory of minima has hardly any successful application, mainly because geometrical indivisibles are postulated rather than used by Bruno. Cavalieri, on the other hand, deserves the credit for being the first to employ indivisibles in early modern geometry, developing a method capable of solving problems of measurement more quickly and directly than the methods handed down from the past (e.g. the method of exhaustion).

A possible explanation for these differences may be the following. While Bruno and Cavalieri were building on insights gained from the Pythagorean tradition, they also had to come to terms with the Aristotelian continuum. The fact, already mentioned, that Cavalieri's method of indivisibles was rejected by his opponents as implying an atomistic view of the continuum tells us that Aristotle was still considered an authority in the field. Therefore, either one openly challenged Aristotle by presenting geometrical indivisibles as an alternative to the Aristotelian continuum or one tried to find a compromise between the two views. In our case, Bruno opted for a more polemical attitude towards Aristotle, while Cavalieri cautiously avoided saying that the indivisibles were part of the continuum. As we shall see, most of the differences between the theories of Bruno and Cavalieri may be explained in terms of their different attitudes towards the Aristotelian orthodoxy.

In the following, I shall first give a brief overview of both Cavalieri's method of indivisibles $(\$ 1)$ and Bruno's theory of minima ( $\$ 2)$. Then, moving from the "kinetic" or "genetic" understanding of geometrical objects displayed in both Bruno's and Cavalieri's theories, I shall reconstruct the earlier history of this understanding by tracing it back to its Pythagorean origins $(\$ 3)$. 


\section{Cavalieri's method of indivisibles}

Cavalieri devotes two of his works to elaborating the method of indivisibles: the Geometria indivisibilibus continuorum nova quadam ratione promota (1635) and the Exercitationes geometricae sex (1647). ${ }^{8}$ The starting point of Cavalieri's method is to determine the indivisibles of a figure. In the case of a plane figure, this can be done by moving a line parallel to itself so as to intersect the figure in question. The intersections between the moving line and the figure are, to use Cavalieri's terminology, "all the lines" of the figure - i.e. its indivisibles. Likewise, the indivisibles of solid figures are "all the planes" obtained by the intersection of a moving plane with the figure. ${ }^{9}$

While indivisibles (points, lines and planes) are already present in classical Euclidean geometry, it is the idea of a set of indivisibles which is entirely new. Indeed, both "all the lines" and "all the planes" are terms coined by Cavalieri to escape the atomistic conclusion that indivisibles are part of the geometrical figure they belong to. Nonetheless, there seems to be little or no information about these new geometrical objects in Cavalieri's works. This has made modern interpreters such as Enrico Giusti wonder about "the ambiguity of the concept of 'all the lines' as a class of magnitudes". ${ }^{10}$ We shall return to the peculiar geometrical status of Cavalieri's indivisibles below.

A second step in Cavalieri's method consists in comparing different figures by means of their indivisibles. Such a comparison is made possible by the fact that, according to "Cavalieri's principle", there is a relationship between the ratio of two figures and that of their indivisibles. More precisely, if the indivisibles of two figures are always in the same ratio, the ratio between the two figures will be equal to that of their indivisibles. ${ }^{11}$ When applied to the computation of areas and volumes, Cavalieri's principle makes it possible to solve a wide range of problems. Indeed, in Giusti's opinion, a major strength of Cavalieri's theory is that it can demonstrate highly general theorems involving classes of geometrical figures. This represents a considerable improvement over the earlier method of exhaustion, which can only deal with one figure at a time. ${ }^{12}$

As we have already mentioned, the publication of Cavalieri's indivisibles led to a controversy which has been the subject of several scholarly studies. Amir Alexander sees in these disputes not only a merely geometrical controversy, but also two competing worldviews clashing over issues of freedom and sovereignty. ${ }^{13}$ Other scholars (such as Paolo Mancosu and Antoni Malet) emphasize the foundational character of these discussions and their philosophical relevance. ${ }^{14}$ Following the latter's lead, I analyze how the issues related to the composition of the continuum affect Cavalieri's method. Preeminently, these issues are raised in the controversy between Cavalieri and the Jesuits Paul Guldin (1577-1643) and André Tacquet (1612-1660). ${ }^{15}$

In Book IV of Guldin's De centro gravitatis (1641) it is objected that, by equating geometrical figures to the sum of their indivisibles, Cavalieri's method advocates an atomistic view of the continuum. ${ }^{16}$ For his part, Cavalieri replies to Guldin by making explicit that in his method there is no assumption regarding the composition of the continuum. ${ }^{17}$ The same applies to the idea that indivisibles can be added up to form geometrical figures, which Cavalieri strives to rule out from his method. On the other hand, the idea underlying Cavalieri's definition of indivisibles - that geometrical objects can be generated by motion - is not dismissed by Guldin or by Tacquet. In fact, as I have already mentioned, 
it was common practice in seventeenth-century mathematics to define geometrical objects in terms of motion.

Tacquet takes issue with Cavalieri's method in his Cylindricorum et Annularium libri IV (1651). Unlike Guldin, Tacquet does not refute indivisibles altogether, but accepts that they may be employed in geometry under one condition - that they are of the same kind as the figure they belong to. This means that indivisibles and their figure must be homogeneous, and thus the indivisibles of a plane must be smaller planes. ${ }^{18}$ In contrast, we have seen that Cavalieri's indivisibles are heterogeneous - they have one dimension less than their figure: the indivisibles of a plane are lines, while the indivisibles of a solid are planes.

Tacquet's criticisms must have been effective, because indivisibles became homogenous magnitudes as a result of innovations introduced during the course of the seventeenth century. In Antoni Malet's opinion, it was precisely this transformation that made possible the passage from indivisibles to infinitesimals. ${ }^{19}$ Yet it is worth noting that, on assuming indivisibles to be homogeneous with their figures, one also accepts that indivisibles are part of their figures - for being homogenous and being a part are the same within the theory of magnitudes supported by Euclidean geometry. In contrast, in presenting indivisibles as heterogeneous magnitudes, Cavalieri's plan was precisely to exclude the idea that indivisibles are part of their figures. However, such a conception would nonetheless be attributed to Cavalieri by his opponents, and eventually prevailed with the emergence of infinitesimals.

\section{Bruno's theory of minima}

In the latter part of his career, Bruno developed an atomistic theory based on the concept of the minimum. Retrospectively, this theory can be regarded as the final act of Bruno's reform of the Aristotelian cosmos. ${ }^{20}$ Such a reform starts with the Italian dialogues (1584-5) in which Bruno shapes his conception of a homogeneous, heliocentric and infinite universe. Although an atomistic conception of matter is adumbrated in these earlier writings, the notion of the minimum is first mentioned in Bruno's dialogues on Fabrizio Mordente's proportional compass (1586). ${ }^{21}$ In the following years, the notion of the minimum is given pride of place in the Articuli adversus mathematicos (1588), Bruno's first attempt to establish an atomistic geometry. But it is only with the publication of Bruno's De triplici minimo et mensura (1591), one of his last printed works, that the geometry of minima finally becomes a theory.

From Kurt Lasswitz's groundbreaking study onwards, Bruno's atomism has attracted increasing interest. ${ }^{22}$ However, less attention has been paid to the geometrical aspect of this theory which constitutes the core of Bruno's mathematics. This may be because of the low esteem in which Bruno's mathematics was held by its earlier commentators. In Hélène Védrine's opinion, for instance, the development of Bruno's mathematics is hindered by the a-priori rejection of Aristotle and the consequent adoption of a Platonic realistic conception of mathematical beings. ${ }^{23}$ However, a new trend has recently emerged in Bruno scholarship which has contributed to a critical reappraisal of Bruno's mathematics. $^{24}$

Bruno's theory envisages three different species of minima - a metaphysical minimum (the monad), a physical minimum (the atom) and a geometrical minimum (the point): 
The minimum is the substance of things and, although it refers to a genus different from that of quantity, constitutes the principle of the quantity and magnitude of bodies. It is matter, that is, element, efficient cause, final cause, totality. It is a point in one- and two-dimensional magnitudes. It is properly named atom in the bodies which are the first parts; and less properly in those entities which are all in all and in the single parts (such as the voice, the soul and similar entities). It is a monad rationally in numbers and essentially in all things. ${ }^{25}$

The monad provides the metaphysical background for Bruno's mathematics and is certainly important for understanding how Bruno came to conceptualize geometrical indivisibles. However, the concept of the monad is absent from Cavalieri's theory and therefore cannot be counted among the elements of knowledge shared by Bruno and Cavalieri. Hence, I leave aside the issue of the metaphysical underpinnings of Bruno's mathematics because it is irrelevant to the purpose of this paper.

By associating point and atom as two species of the same minimum, Bruno leaves no doubt as to the composition of both physical and geometrical objects out of indivisibles; just as bodies are composed of atoms, so geometrical objects are composed of points. The belief in what may be called the isomorphism of physical and geometrical objects is reflected in several aspects of Bruno's theory. First of all, points and atoms have the same shape, the former being a circle and the latter being a sphere. ${ }^{26}$ This image is not only described in words but is also shown in Bruno's diagrams, which makes him one of the first in the history of science to visually represent points and atoms as circles and spheres. $^{27}$

The fact that Bruno's indivisibles are circular in shape and eo ipso extended is one of the major differences between Bruno's and Cavalieri's theories. We have seen how Cavalieri makes it very clear that indivisibles have one dimension less than their figures and thus have no thickness or extension whatsoever. This, in turn, enables Cavalieri to argue that indivisibles are not part of the continuum. In Bruno's theory, on the contrary, the continuum is explicitly assumed to be composed of indivisibles, and nothing prevents indivisibles from being extended.

At the same time, accepting the extension of indivisibles implies that the number of indivisibles composing a geometrical figure must be finite, otherwise the extension of the figure would be exceeded by the extension of all its indivisibles taken together. This is no problem in physics where in fact Bruno claims that every finite bodily entity consists of a finite number of parts, ${ }^{28}$ but may cause inconvenience when it comes to geometry. If geometrical objects are composed of a finite number of indivisibles, they are always commensurable in terms of their indivisibles. Consequently, Bruno is forced to deny the existence of incommensurable magnitudes, although this is presented as a great achievement of his theory: "Maybe, oh illustrious master, should I complain about the dissolution of incommensurability and irrationality, instead of being glad for the revival of rationality and measurability?". ${ }^{29}$

Given the atomistic character of Bruno's theory, it should not come as a surprise that the Aristotelian notion of infinite divisibility is considered by Bruno to be "the principle of all the mistakes both in physics and mathematics". ${ }^{30}$ It is worth noticing that, in making his argument against Aristotle, Bruno's strategy is different from that adopted to build up his theory. Here, Bruno does not rely on the isomorphism of physical and geometrical objects to apply the same argument to both realms; rather, infinite divisibility is first dismissed in the case of nature by arguing that if physical objects were infinitely divisible, they 
would be composed of an infinite number of parts. Accordingly, there would be no difference between a fruit and the entire world, to take an example given by Bruno in a work entitled Camoeracensis acrotismus (1588), for it is impossible that "an infinite can be bigger than another infinite either in potency or in act". ${ }^{31}$

Then, after having denied the Aristotelian concept of infinite divisibility in physics, Bruno goes on to dismiss the same concept in mathematics. For Bruno, mathematics is subordinate to physics insofar as an operation which can be carried out only in mathematics but not in nature is nonsense. Hence, although geometrical objects could be infinitely divided, it would be pointless to perform a mathematical operation which has no counterpart in nature: "When infinitely dividing what has a precise measure, the geometer makes a mistake, he does not follow in the footsteps of nature which, being never reached, cannot be imitated by the geometer". ${ }^{32}$

If on the one hand Bruno attacks Aristotle for his notion of infinite divisibility, on the other hand he defends his theory from Aristotle's objections against atomism. For Aristotle, the composition of the continuum out of indivisibles is excluded by the very definition of the continuum, whose parts must be in contact with each other. ${ }^{33}$ Now, this contact can occur in two ways: one part touches the other either with all or with a part of itself. But if two indivisibles touch each other with all of themselves, they overlap and thus do not create any extension. On the other hand, indivisibles have no part at all, so they cannot enter into contact in the second way.

Bruno tries to solve this conundrum by considering a third possibility - that the contact between minima occurs through their extremity (terminus). ${ }^{34}$ The extremity is neither part of the minimum nor an entity of its own, because the extremity is less than a minimum and exists only when two minima touch each other. The extremity is therefore ontologically dependent on the minimum.

The concept of extremity is also central to Euclidean geometry wherein points and lines are precisely defined in terms of extremity: "the extremities of the line are points", 35 and "the extremities of the surface are lines". ${ }^{36}$ Working on Proclus's Commentary on these two Euclidean definitions, Ruth Glasner has highlighted how in ancient mathematics there are essentially two ways of defining geometrical objects: the Euclidean and the Pythagorean. ${ }^{37}$ In the Euclidean way, lower dimensions are defined in terms of the higher through the concept of extremity. The Pythagorean way however moves in the opposite direction, defining the higher dimensions in terms of the lower by appealing to motion. Bruno offers a clear example of the Pythagorean way of defining geometrical objects: "The line is nothing more than a moved point, the plane is nothing more than a moved line, the solid is nothing more than a moved surface" ${ }^{38}$

One might argue that motion is also used by Euclid to define geometrical objects, such as in Book XII of the Elements where a kinetic understanding of the cone, the cylinder and the sphere is found. Yet, as we shall see in the next section, the idea that geometrical objects are generated by motion predates Euclid, it being traditionally ascribed to the Pythagoreans. As to Bruno, endowing points with motion adds a new element to the parallel between geometrical and physical objects - for Bruno's "soul-powered atoms", to borrow Hilary Gatti's expression, are also capable of moving, driven by the world soul which is in them. ${ }^{39}$ Taken together, all of these analogies suggest that there is a close relationship between geometry and nature in Bruno's mind. The study of this relationship is left for future work. 


\section{Pythagorean mathematics and the idea of motion}

In mathematics, the idea that geometrical objects are generated by motion is applied in both constructions and the so-called "genetic definitions". The latter, in which geometrical objects are referred to in terms of their generation, were particularly widespread in early modern times. Among those who make use of genetic definitions in this period are Spinoza, Hobbes and Newton, as well as Bruno and Cavalieri. Furthermore, genetic definitions such as "the line is the flowing of a point" are found in almost every sixteenth-century commentary on Euclid's Elements (including those of Peletier, Clavius, Commandino and Billingsley), although such definitions do not feature among those originally provided by Euclid. ${ }^{40}$

Therefore, in establishing their own theories, Bruno and Cavalieri build on a concept that of motion as the generative cause of geometrical objects - which is already present in the mathematical culture of the time. In the case of Bruno, as we shall see, the atomistic framework of his theory requires him to adjust the concept accordingly. Nonetheless, the concept itself remains part of the body of knowledge that Bruno and Cavalieri inherit from antiquity and share with their contemporaries.

It is Sextus Empiricus (c. 160-210 A.D.) who, in his Against the Physicists, informs us that a dynamic generation of geometrical objects is envisioned by the Pythagoreans. In Sextus's account, the Pythagoreans have two theories to explain the generation of geometrical objects. In the first theory, the sequence point-line-surface-solid is associated with the first four numbers in the following way: point-one, line-two, plane-three, solid-four. ${ }^{41}$ Francis Cornford has suggested that each of these numbers corresponds to the minimum number of points required to define the figure in question: one for the point, two for the line, three for the triangle (i.e. the minimum plane) and four for the pyramid (i.e. the minimum solid). ${ }^{42}$ The second theory expounded by Sextus appeals to the notion of flowing:

But some [Pythagoreans] assert that the body is constructed from one point; for this point when it has flowed produces the line, and the line when it has flowed makes the plane, and this when it has moved towards depth generates the body, which has three dimensions. ${ }^{43}$

To be fair, the genuine Pythagorean origin of this theory is questioned by modern commentators. William Guthrie assigns the authorship of the "fluxion theory" to Xenocrates (c. 396/5-314/3 B.C.), arguing that "any modification of Pythagorean doctrine made in the Academy would have been freely accepted as Pythagorean by most neo-Pythagorean and later writers". ${ }^{44}$ On the contrary, after a detailed reconstruction of the geometrical theories elaborated by Plato and his followers, J. A. Philip rules out the idea that the fluxion theory originated in the Academy. He claims that all the alleged Pythagorean theories of the generation of geometrical objects were a "pastiche of doctrines of the Early Academy" developed at a later stage. ${ }^{45}$ But, sidestepping questions of authorship, the fact remains that the fluxion theory was perceived as Pythagorean in antiquity.

Besides Euclid, one of the first mathematicians to employ the notion of flowing is Hero of Alexandria (c. 10-70 A.D.). In his Definitions, Hero writes:

The unit is the principle of numbers, while the point is the principle of geometrical objects. Both are the principle of a series, nevertheless the unit is part of the number, whereas the

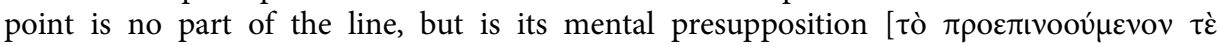




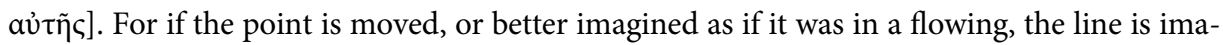
gined. In this way, the point is the principle of the line, and the surface [is the principle] of the solid body. ${ }^{46}$

With the notion of flowing Hero contrasts the atomistic view that geometrical objects consist of points placed side by side. This is in line with Cornford's claim that the fluxion theory is a refinement of the view that magnitudes are composed of points. ${ }^{47}$ Despite the difficulties inherent to this latter view, for Hero the point remains the principle of geometrical objects. This allows for a comparison between point and unit, the latter being defined as the principle of numbers. To avoid saying that the point is part of geometrical objects and yet establish a causal relationship between the two, Hero resorts to the notion of flowing. By doing so, Hero turns the point from the material to the generative principle of the line.

The figure of Hero was known in the Renaissance and so were his Definitions, edited and translated into Latin in 1570 by Conrad Dasypodius. ${ }^{48}$ Hence, Hero's Definitions may have contributed to spreading the notion of flowing in early modern mathematics. A decisive influence on Renaissance mathematics and philosophy of mathematics was also played by Proclus's Commentary on the First Book of Euclid's Elements. ${ }^{49}$ In this work, Proclus (412-485 A.D.) describes the line as the flowing of a point in commenting on the Euclidean definition:

The line has also been defined in other ways. Some define it as the "flowing of a point [jóøıৎ

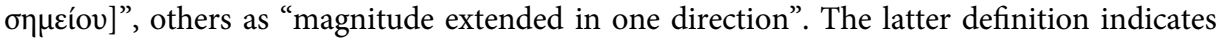
perfectly the nature of the line, but that which calls it the flowing of a point appears to explain it in terms of its generative cause and sets before us not the line in general, but the material line. ${ }^{50}$

The flowing of a point is presented by Proclus as an alternative definition of the line. However, this definition is not only reported by Proclus but also framed in terms of his own philosophy of mathematics. Like Hero, Proclus conceives the flowing of a point as the generative cause of the line. Furthermore, Proclus emphasizes that the flowing of a point does not describe "the line in general, but the material line". What does Proclus mean by the "material line"? The answer may be found in Proclus's ontology of mathematical objects. Following Plato, Proclus places mathematical objects in between pure ideas and sensible things. For mathematical objects are intelligible and eternal like ideas, and extended and divisible like sensible things. ${ }^{51}$ In turn, this requires that mathematical

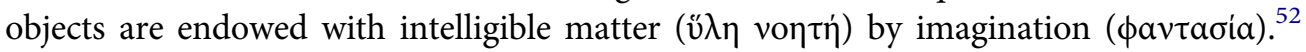
Hence, the material line associated by Proclus to the flowing of the point may be the line as "projected" in the imagination.

The case of Proclus shows us that the meaning attached to the notion of flowing may change depending on the context. Another example of how the concept of flowing is employed in a different philosophical framework is provided by John Philoponus's theory of time. ${ }^{53}$ Hero's concept of flowing proves to be more, so to say, versatile, since it can be isolated from Hero's own philosophy of mathematics. In addition, Hero establishes a relationship between motion and continuum by opposing the composition of geometrical objects out of points with the notion of flowing.

This opposition is found to still be at work in early modern mathematics, wherein advocates of the Aristotelian continuum appeal to motion as opposed to geometrical 
indivisibles. We have seen how, while rejecting Cavalieri's indivisibles, Guldin and Tacquet admit that geometrical objects are generated by motion. Similarly, in his commentary on Euclid's Elements (1557), Jacques Peletier (1517-1582) writes:

Unlike the number which is composed of units, the line is not composed of points, but of a continuous flowing of points. In this respect, the continuum is different from the discrete, as the continuum can be infinitely divided, and [in the continuum] the point is never reached, while in the discrete the unit is reached. ${ }^{54}$

Like Hero, early modern mathematicians use motion to bridge the gap between the discreteness of the point and the continuity of the line without committing to atomism. But if the notion of flowing offers a way to escape the consequences of atomism then how is the same notion interpreted by Bruno, who instead believes that geometrical objects have an atomic structure?

Bruno claims that the line flows into a "multiplication of points" ${ }^{55}$ In saying this, he seems to suggest that the flowing of a point may be envisioned as a repetition of points throughout geometrical space. This image may be described in atomic terms. For instance, think of the point that flows as existing in one place at a certain instant and in another adjacent place at the subsequent instant. This description is compatible with at least two different conceptualizations of flowing, depending on whether space is assumed to have a continuous or an atomic structure. A similar dualism is also found in the medieval debate on the forma fluens/fluxus formae. ${ }^{56}$

If space is a continuous entity, as conceived by Hero, then between two adjacent points there are infinitely many other points in which the flowing can take place. In this case, the flowing (i.e. the line) is something different from the two positions occupied by the point in its motion (i.e. the ends of the line). Accordingly, the line is not composed of points, which is exactly what Hero intends to deny by saying that the line is the flowing of a point. However, if space has an atomic structure, as Bruno has it, then between two adjacent points there is no space left for the flowing to occur. Hence, the flowing does not exist separately from the moving point, but rather is the sum of all the adjacent positions occupied by the point in its motion. This latter option seems to agree better with Bruno's atomistic geometry and his claim that the line flows into a multiplication of points.

\section{Conclusions}

One might well argue that between Bruno's and Cavalieri's theories of indivisibles there are more differences than similarities. This is certainly true and indeed, as already mentioned in the introduction, it is not the purpose of this paper to claim that Bruno is a source or forerunner of Cavalieri. Rather, attention has been drawn to the fact that two theories of indivisibles were independently developed at about the same time. This raises the question about the knowledge underlying geometrical indivisibles, and whether Bruno and Cavalieri shared the same knowledge. I have highlighted how both Bruno's and Cavalieri's theories rest on a kinetic understanding of geometrical objects which modern mathematicians inherited from the ancient Pythagoreans. Also, I have pointed out how shared knowledge can explain Bruno's and Cavalieri's different conceptualizations of indivisibles as being originated in an opposite approach to the same philosophical tradition, that is, Aristotelianism. 
In his From Indivisibles to Infinitesimals, Antoni Malet claims that in early modern times "attacks on the Aristotelian continuum came from more than one direction", adding however that "how well mathematical practitioners accepted these ideas, we do not know". 57 The comparison between Bruno and Cavalieri presented herein helps to fill this gap by highlighting the historical and cultural context in which indivisibles worked their way through early modern geometry. If in Bruno's case indivisibles offered a means to advocate an atomistic view of the continuum, Cavalieri openly denied that indivisibles play a role in the composition of the continuum in order to avoid challenging the Aristotelian orthodoxy. But Aristotle's authority must have lost its grip by the time Cavalieri's theory gained supporters, since these later mathematicians had no trouble assuming geometrical figures to be the sum of their indivisibles.

Hence, we can conclude that the erosion of Aristotelian thought gave way to a period of great progress in geometry, culminating in the invention of the calculus by Leibniz and Newton. Both Bruno and Cavalieri, despite their different attitudes towards Aristotle, made important contributions to this progress, reopening the question of the relationship between continuity and indivisibility in geometry and - especially Cavalieri - paving the way for a new line of research. From a historiographical perspective, this further confirms that the development of mathematics and science over time is not merely due to the breakthroughs of lone individuals, but is always the result of the intellectual climate wherein such breakthroughs are made. This climate, in turn, cannot be understood apart from the actors who created it, including the "minor characters" such as Bruno. This paper was devoted to those characters in an attempt to put them on the map.

\section{Notes}

1. See Aristotle, The Complete Works, 861ff (Physics, 6, 231a18ff).

2. For a history of the problem of the continuum, see Lasswitz, Geschichte der Atomistik; Pyle, Atomism and Its Critics; Lüthy, Murdoch, and Newman, Late Medieval and Early Modern Corpuscular Matter Theories; Grellard and Robert, Atomism in Medieval Philosophy.

3. See Leibniz, Theodicy, 53.

4. See Renn, "Historical Epistemology and Interdisciplinarity", 241-51.

5. Schemmel, The English Galileo, xi.

6. Jullien, "Explaining the Sudden Rise", 6-8.

7. Schemmel, The English Galileo, 6.

8. For a general overview of Cavalieri's method, see Lombardo-Radice's introduction to Cavalieri, Geometria degli indivisibili; Andersen, "Cavalieri's Method of Indivisibles"; Baroncelli, "Bonaventura Cavalieri"; Boulier, "Le problème du continu".

9. See Cavalieri, Geometria indivisibilibus continuorum, Book II, 1-2.

10. Giusti, Cavalieri and the Theory of Indivisibles, 64.

11. See Cavalieri, Geometria indivisibilibus continuorum, Book II, 20-2. "Figurae planae habent inter se eadem rationem, quam eorum omnes lineae iuxta quamvis regulam assumptae. Et figurae solidae, quam eorum omnia plana iuxta quamvis regulam assumpta”.

12. See Giusti, Cavalieri and the Theory of Indivisibles, 24-5.

13. See Alexander, Infinitesimal.

14. See Mancosu, Philosophy of Mathematics, 34-64; Malet, From Indivisibles to Infinitesimals, $11-22$.

15. For Guldin's criticisms of Cavalieri's method, see Giusti, Cavalieri and the Theory of Indivisibles, 55-65, 73-6; Mancosu, Philosophy of Mathematics, 50-5; Festa, "Aspects de la controverse". For Tacquet's criticisms, see Descotes, "Two Jesuits against the Indivisibles". 
16. See especially Guldin, De centro gravitatis, 340: "Hoc meo iudicio a nullo obtinebit Geometra, nunquam enim superficies vocari potest plures, vel omnes lineae; cum linearum multitudo quantumvis maxima, ne minimam quidem componere queat superficiem".

17. See Cavalieri, Exercitationes geometricae sex, 199: "Apud eos enim, qui sustinent continuum ex indivisibilibus componi, descriptio dictorum indivisibilium erit descriptio superficiei. Apud eos vero, qui ulta haec indivisibilia ponunt aliquid aliud in ipso continuo, illud dicendum erit, describi in ipso motu".

18. See Tacquet, Cylindricorum et Annularium libri, 23-4: "Admittunt quidem geometrae lineam generari ex fluxu puncti; superficiem ex fluente linea; corpus ex superficie. Sed aliud longe est ex indivisibilium fluxu quantitatis species generari; aliud ex indivisibilibus componi. [...] Hoc solum dico demonstrationes per heterogeneas institutas ad assensum non cogere; nisi, quod fieri plerumque potest, ad homogenea reducantur".

19. See Malet, From Indivisibles to Infinitesimals, 17-19.

20. For a recent and extensive overview of different aspects of Bruno's thought, see Ciliberto, Bruno, Parole, concetti, immagini. On Bruno's cosmology, see Michel, La cosmologie de Bruno; Granada, "Aristotle, Copernicus, Bruno".

21. Bruno, Due dialoghi sconosciuti.

22. On Bruno's atomism, see Lasswitz, Geschichte der Atomistik, 359-401; Atanasijević, Metaphysical and Geometrical Doctrine; Michel, "Atomisme de Giordano Bruno"; Monti's introduction to Bruno, Opere latine; Seidengart, "Metaphysique du minimum indivisible"; Lüthy, "Entiae \& sphaerae"; Gatti, "Bruno's Soul-Powered Atoms"; Matteoli, "Materia, minimo e misura".

23. Védrine, "L'obstacle réaliste".

24. On Bruno's mathematics, see Aquilecchia, "Bruno e la matematica"; Bönker-Vallon, Metaphysik und Mathematik; Bönker-Vallon, "Bruno e Proclo"; Bönker-Vallon, "Bruno e la matematica"; De Bernart, Numerus quodammodo infinitus.

25. Bruno, "De minimo", 139-40: "Minimum est substantia rerum, quatenus videlicet aliud a quantitatis genere significatur, corporearum vero magnitudinum prout est quantitatis principium. Est, inquam, materia seu elemen tum, efficiens, finis et totum, punctum in magnitudine unius et duarum dimensionum, atomus privative in corporibus quae sunt primae partes, atomus negative in iisce quae sunt tota in toto atque singulis, ut in voce, anima et huiusmodi genus, monas rationaliter in numeris, essentialiter in omnibus". All translations are my own.

26. Ibid., 177: "Minimi in plano propria figura est circulus, in solido sphaera".

27. On Bruno's use of diagrams, see Lüthy, "Bruno's Area Democriti”; Lüthy, "Entiae \& sphaerae".

28. See Bruno, "De minimo", 150: "Materies coram finita recepta finitis prorsus consistit partibus omnis".

29. Ibid., 240: "Numquid, o amplissime domine magister, pro interitu alogiae et incommensurabilitatis potius plorandum censebo, quam pro logiae et mensurae renascentia gaudendum?".

30. Ibid., 153: "Principium et fundamentum errorum omnium, tum in physica tum in mathesi, est resolutio continui in infinitum".

31. Bruno, "Camoeracensis acrotismus", 153: "Quomodo unum infinitum est maius alio in potentia vel in actu?".

32. Bruno, "De minimo", 154-5: "Ergo errat mensor certum sine fine resolvens quantum, naturae nusquam vestigia lustrans, nusquam illa attingens, non ullis sortibus aequans".

33. See Aristotle, The Complete Works, 861-2 (Physics, 6, 231a18-231a28).

34. See Bruno, "De minimo", 160: "Minimum non tangit se toto neque sui parte alterum minimum, sed suo fine plura potest attingere minima, sicut etiam nullum corpus se toto vel parte sui, sed vel tota vel extremitatis parte tangit alterum; [...] terminus ergo est qui nulla est pars, et per consequens neque minima pars".

35. Euclid, Elements, 165 (def. I, 3).

36. Ibid., 171 (def. I, 6).

37. See Glasner, "Proclus' Commentary", 320-8.

38. Bruno, "De minimo", 148: "Ergo linea nihil est nisi punctus motus, superficies nisi linea mota, corpus nisi superficies mota, et consequenter punctus mobilis est substantia omnium, et punctus manens est totum". 
39. See Gatti, "Bruno's Soul-Powered Atoms”.

40. See Peletier, In Euclidis Elementa, 2; Billingsley, The Elements of Geometrie, fol. 1r; Commandino, Gli elementi d'Euclide, fol. 1v; Clavius, Commentaria in Euclidis Elementa geometrica, 13-4.

41. See Sextus Empiricus, Against the Physicists, 345-6.

42. Cornford, Plato and Parmenides, 12.

43. Sextus Empiricus, Against the Physicists, 346.

44. Guthrie, History of Greek Philosophy, 262.

45. Philip, "The 'Pythagorean' Theory", 40.

46. Hero of Alexandria, Opera quae supersunt omnia, 14. Following Giardina's Italian trans-

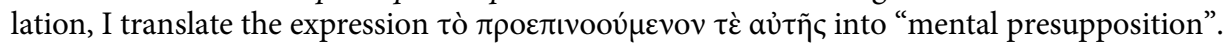
For a more detailed analysis of the passage in question, see Giardina, Erone di Alessandria, 249-65.

47. See Cornford, Plato and Parmenides, 12.

48. For the reception of Hero's works in the Renaissance, see Trabucco, L'opere stupende. Dasypodius's translation of Hero's Definitions is included in Dasypodius, Euclidis Elementorum liber primus.

49. For the most part, the fortune of Proclus's Commentary in the Renaissance has been studied in relation to the Quaestio de certitudine mathematicarum; see Jardine, "Epistemology of the Sciences”; De Pace, Le matematiche; Mancosu, Philosophy of Mathematics, 10-33; Sergio, Verità matematiche, 11-52.

50. Proclus, Commentary, 79 (97, 6-17). For a detailed analysis of the historical development of the concept of flowing in ancient mathematics, see Vinel, "La rhusis mathematique".

51. See Proclus, Commentary, 3 (3, 1-14).

52. See ibid., $42(52,26-53,1)$.

53. For John Philoponus's theory of time, see McGinnis, "For Every Time".

54. Peletier, In Euclidis Elementa, 2: "Non igitur sicut ex accumulatis unitatibus sit numerus, sic ex additis punctis sit linea, sed ex ipsorum fluxu continuo. Atque in hoc differt continuum a discreto, quod continuum infinite dividatur, neque ad punctum unquam deveniatur, ut in discretis ad unitatem". On Peletier's Euclid commentary, see Axworthy, "The Ontological Status".

55. See Bruno, "Articuli adversus mathematicos", 34: "Lineam vero quae minima pars est, aliam quidem plani, cuius latitudo punctum non excedit, ex punctis in longum dispositis (in quorum multiplicationem defluit) intelligo compositam" (emphasis added).

56. See McGinnis, "Medieval Arabic Analysis".

57. Malet, From Indivisibles to Infinitesimals, 11.

\section{Disclosure statement}

No potential conflict of interest was reported by the author.

\section{Acknowledgements}

I would like to express my gratitude to my supervisors Michele Ciliberto and Aurélien Robert for their support, and to Marco Matteoli for having introduced me to Bruno's mathematics. Special thanks to the two anonymous referees and the editor of this journal, Stephen Clucas, who, with their insightful comments and suggestions, contributed to improve and clarify the argument of this article.

\section{Notes on contributor}

Paolo Rossini is a $\mathrm{PhD}$ candidate at the Scuola Normale Superiore (Pisa). He is currently writing his dissertation on Giordano Bruno and the problem of mathematical infinity. 


\section{Bibliography}

Alexander, Amir. Infinitesimal: How a Dangerous Mathematical Theory Shaped the Modern World. New York: Farrar, Straus and Giroux, 2014.

Andersen, Kirsti. "Cavalieri's Method of Indivisibles". Archive for History of Exact Sciences 31, no. 4 (1985): 291-367.

Aquilecchia, Giovanni. "Bruno e la matematica a lui contemporanea". In Schede bruniane: 19501992, 311-317. Milan: Vecchiarelli, 1993.

Aristotle. The Complete Works of Aristotle. The Revised Oxford Translation. Vol. I and II. Edited by Jonathan Barnes. Princeton, NJ: Princeton University Press, 1995.

Atanasijević, Ksenija. The Metaphysical and Geometrical Doctrine of Bruno, as Given in His Work De triplici minimo. Translated by G. V. Tomashevich. St. Louis, Missouri: W. H. Green, 1972.

Axworthy, Angela. "The Ontological Status of Geometrical Objects in the Commentary on the Elements of Euclid of Jacques Peletier du Mans (1517-1582)", 2013. https://halshs.archivesouvertes.fr/halshs-00855348/.

Baroncelli, Giovanna. "Bonaventura Cavalieri tra matematica e fisica". In Geometria e atomismo nella scuola galileiana, edited by Massimo Bucciantini, and Maurizio Torrini, 67-101. Florence: Leo S. Olschki, 1992.

Billingsley, Henry. The Elements of Geometrie of the Most Ancient Philosopher Euclide of Megara. London: John Daye, 1570.

Bönker-Vallon, Angelika. "Bruno e Proclo: connessioni e differenze tra la matematica neoplatonica e quella bruniana”. In La filosofia di Giordano Bruno. Problemi ermeneutici e storiografici, edited by Eugenio Canone, 129-144. Florence: Leo S. Olschki, 2003.

Bönker-Vallon, Angelika. "Giordano Bruno e la matematica". Rinascimento (Florence, Italy) 39 (1999): 67-93.

Bönker-Vallon, Angelika. Metaphysik und Mathematik bei Giordano Bruno. Berlin: Akademie Verlag, 1995.

Boulier, Philippe. "Le problème du continu pour la mathématisation galiléenne et la géométrie cavalierenne". Early Science and Medicine 15 (2010): 371-409.

Bruno, Giordano. "Camoeracensis acrotismus". In Opera latine conscripta publicis sumptibus edita. Vol. I, Pars I, edited by F. Fiorentino, 53-190. Neaples: Morano, 1879.

Bruno, Giordano. "Articuli adversus mathematicos". In Opera latine conscripta. publicis sumptibus edita Vol. 1, Pars III, edited by F. Tocco, and H. Vitelli, 1-118. Florence: Le Monnier, 1889.

Bruno, Giordano. "De triplici minimo et mensura". In Opera latine conscripta publicis sumptibus edita, Vol. 1, Pars III, edited by F. Tocco, and H. Vitelli, 119-361. Florence: Le Monnier, 1889.

Bruno, Giordano. Due dialoghi sconosciuti e due dialoghi noti. Idiota triumphans, De somni interpretatione, Mordentius, De Mordenti circino. Edited by Giovanni Aquilecchia. Rome: Edizioni di storia e letteratura, 1957.

Bruno, Giordano. Opere Latine. Translated by Carlo Monti. Torino: Unione tipografico-editrice torinese, 1980.

Cavalieri, Bonaventura. Exercitationes geometricae sex. Bologna: Monti, 1647.

Cavalieri, Bonaventura. Geometria indivisibilibus continuorum nova quadam ratione promota. Bologna: Monti, 1635.

Cavalieri, Bonaventura. Geometria degli indivisibili. Translated by Lucio Lombardo-Radice. Torino: Unione tipografico-editrice torinese, 1966.

Ciliberto, Michele, ed. Giordano Bruno, Parole, concetti, immagini. 3 vols. Pisa: Edizioni della Normale, 2014.

Clavius, Christophorus. Commentaria in Euclidis Elementa geometrica. Mainz: Hierat, 1611. [Reprinted, Hildesheim: Olms-Weidmann, 1999].

Commandino, Federico. De gli elementi d'Euclide libri quindici. Urbino: Domenico Frisolino, 1575.

Cornford, Francis M. Plato and Parmenides. Parmenides' Way of Truth and Plato's Parmenides Translated with an Introduction and a Running Commentary. London: Routledge, 1964.

Dasypodius, Conrad. Euclidis Elementorum liber primus. Heroni Alexandrini vocabula geometrica. Strasbourg: Myly, 1570. 
De Bernart, Luciana. Numerus quodammodo infinitus: per un approccio storico-teorico al dilemma matematico nella filosofia di Giordano Bruno. Rome: Edizioni di storia e letteratura, 2002.

De Pace, Anna. Le matematiche e il mondo. Ricerche su un dibattito in Italia nella seconda metà del Cinquecento. Milan: Franco Angeli, 1993.

Descotes, Dominique. “Two Jesuits against the Indivisibles”. In Seventeenth-Century Indivisibles Revisited, edited by Vincent Jullien, 249-274. Basel: Birkhäuser, 2015.

Euclid. The Thirteen Books of Euclid's Elements. Vol. I (Books I and II). Edited by Thomas L. Heath. New York: Dover, 2016.

Festa, Egidio. "Aspects de la controverse sur les indivisibles". In Geometria e atomismo nella scuola galileiana, edited by Massimo Bucciantini, and Maurizio Torrini, 193-207. Florence: Leo S. Olschki, 1992.

Gatti, Hillary. “Giordano Bruno's Soul-Powered Atoms: From Ancient Sources Towards Modern Science". In Late Medieval and Early Modern Corpuscular Matter Theories, edited by Christoph Lüthy, John E. Murdoch, and William R. Newman, 163-180. Leiden: Brill, 2001.

Giardina, Giovanna R. Erone di Alessandria: le radici filosofico-matematiche della tecnologia applicata. Definitiones: testo, traduzione e commento. Catania: CUECM, 2003.

Giusti, Enrico. Bonaventura Cavalieri and the Theory of Indivisibles. Cremona: Edizioni Cremonese, 1980.

Glasner, Ruth. "Proclus' Commentary on Euclid's Definitions 1, 3 and 1, 6". Hermes 120, no. 3 (1992): 320-333.

Granada, Miguel A. "Aristotle, Copernicus, Bruno: Centrality, the Principle of Movement and the Extension of the Universe". Studies in History and Philosophy of Science Part A 35 (2004): 91114.

Grellard, Christophe, and Aurélien Robert, eds. Atomism in Late Medieval Philosophy and Theology. Leiden: Brill, 2009.

Guldin, Paul. De centro gravitatis, Liber Quartus. Wien: Matthaei Cosmerovij, 1641.

Guthrie, William K. C. A History of Greek Philosophy. Vol. I: The Earlier Presocratics and the Pythagoreans. Cambridge: Cambridge University Press, 1962.

Hero of Alexandria. Opera quae supersunt omnia. Vol. IV: Definitiones. Edited by J. L. Heiberg. Stuttgart: B.G. Teubner, 1903.

Jardine, Nicholas. "Epistemology of the Sciences". In The Cambridge History of Renaissance Philosophy, edited by Charles B. Schmitt, and Quentin Skinner, 685-711. Cambridge: Cambridge University Press, 1998.

Jullien, Vincent. "Explaining the Sudden Rise of Methods of Indivisibles". In Seventeenth-Century Indivisibles Revisited, edited by Vincent Jullien, 1-18. Basel: Birkhäuser, 2015.

Lasswitz, Kurd. Geschichte der Atomistik vom Mittelalter bis Newton. Hamburg: Leopold Voss, 1890.

Leibniz, Gottfried Wilhelm. Theodicy: Essays on the Goodness of God, the Freedom of Man and the Origins of Evil. Translated by Austin Marsden Farrer. Chicago: Open Court Publishing, 1985.

Lüthy, Christoph. "Bruno's 'Area Democriti' and the Origins of Atomist Imagery". Bruniana \& Campanelliana 4, no. 1 (1998): 59-92.

Lüthy, Christoph. "Entiae \& sphaerae: due aspetti dell'atomismo bruniano". In La filosofia di Giordano Bruno. Problemi ermeneutici e storiografici, edited by Eugenio Canone, 165-198. Florence: Leo S. Olschki, 2003.

Lüthy, Christoph, John E. Murdoch, and William R. Newman, eds. Late Medieval and Early Modern Corpuscular Matter Theories. Leiden: Brill, 2001.

Malet, Antoni. From Indivisibles to Infinitesimals. Studies on Seventeenth-Century Mathematizations of Infinitely Small Quantities. Bellaterra: Universitat Autònoma de Barcelona. Servei de Publicacions, 1996.

Mancosu, Paolo. Philosophy of Mathematics and Mathematical Practice in the Seventeenth Century. Oxford: Oxford University Press, 1996.

Matteoli, Marco. "Materia, minimo e misura: la genesi dell'atomismo 'geometrico' in Giordano Bruno". Rinascimento (Florence, Italy) 50 (2010): 425-449. 
McGinnis, Jon. "For Every Time There Is a Season: John Philoponus on Plato's and Aristotle's Conception of Time”. KronoScope 3, no. 1 (2003): 83-111.

McGinnis, Jon. "A Medieval Arabic Analysis of Motion at an Instant: The Avicennan Sources to the Forma Fluens / Fluxus Formae Debate”. The British Journal for the History of Science 39, no. 02 (2006): 189-205.

Michel, Paul-Henri. "L'atomisme de Giordano Bruno". In La science au XVI siècle. Colloque international de Royaumont, 249-264. Paris: Hermann, 1960.

Michel, Paul-Henri. La cosmologie de Giordano Bruno. Paris: Hermann, 1962.

Peletier, Jacques. In Euclidis Elementa geometrica demostrationum. Libri sex. Paris: Tornaesium, 1557.

Philip, J. A. “The 'Pythagorean' Theory of the Derivation of Magnitudes”. Phoenix 20, no. 1 (1966): 32-50.

Proclus. A Commentary on the First Book of Euclid's Elements. Translated by G. R. Morrow. Princeton, NJ: Princeton University Press, 1992.

Pyle, Andrew. Atomism and Its Critics: From Democritus to Newton. Bristol: Thoemmes Press, 1997.

Renn, Jürgen. "Historical Epistemology and Interdisciplinarity". In Physics, Philosophy, and the Scientific Community. Essays in the History and Philosophy of Natural Sciences and Mathematics In Honor of Robert S. Cohen, edited by Kostas Gavroglu, John Stachel, and Marx W. Wartofsky, 241-251. Dordrecht: Springer, 1995.

Schemmel, Matthias. The English Galileo: Thomas Harriot's Work on Motion as an Example of Preclassical Mechanics. Heidelberg: Springer, 2008.

Seidengart, Jean. "La metaphysique du minimum indivisible et la réforme des mathématiques chez Giordano Bruno". In Atomismo e continuo nel XVII secolo, edited by Egidio Festa, and Romano Gatto, 55-86. Neaples: Vivarium, 2000.

Sergio, Emilio. Verità matematiche e forme della natura da Galileo a Newton. Rome: Aracne, 2006. Sextus Empiricus. Against the Physicists. Against the Ethicists. Translated by Robert Gregg Bury. Cambridge, MA: Harvard University Press, 1968.

Tacquet, André. Cylindricorum et Annularium libri IV. Antwerp: Jacob Meursius, 1651.

Trabucco, Oreste. L'opere stupende dell'arti più ingegnose: la recezione degli Pneumatika di Erone Alessandrino nella cultura italiana del Cinquecento. Florence: Leo S. Olschki, 2010.

Vinel, Nicolas. "La rhusis mathmatique. De l'ancien Pythagorisme à Proclus". In Études sur le Commentaire de Proclus au premier livre des Éléments d'Euclide, edited by Alain Lernould, 111-124. Villeneuve d'Ascq: Presses Universitaires du Septentrion, 2010.

Védrine, Hélène. "L'obstacle réaliste en mathématique chez deux philosophes du XVI siècle: Bruno et Patrizi”. In Platon et Aristote à la Renaissance (XVI Colloque International de Tours), edited by J.-C. Margolin, and M. Gandillac, 239-248. Paris: Vrin, 1976. 